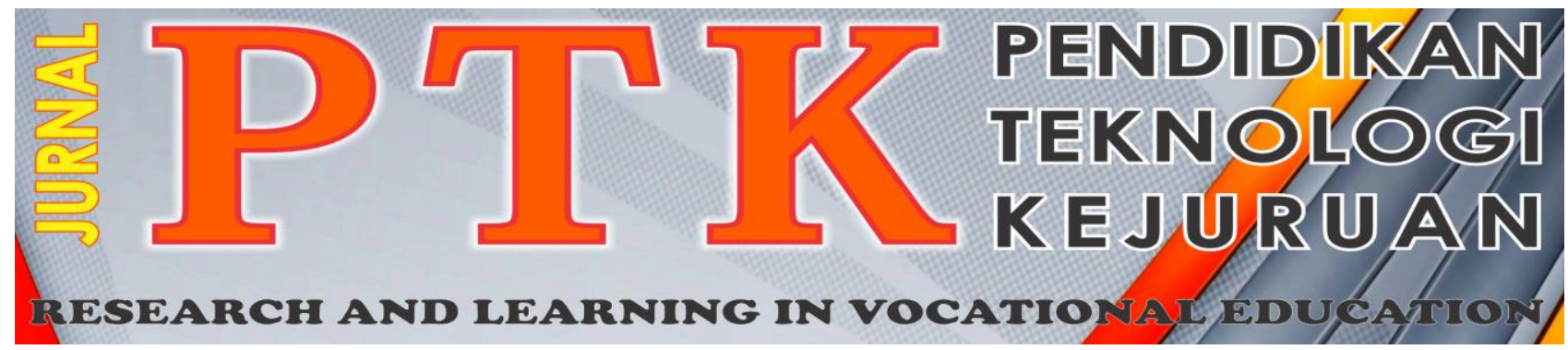

Vol. 1, No. 32018

P-ISSN: 2621-3273

E-ISSN 2621-1548

\title{
PENGEMBANGAN MEDIA PEMBELAJARAN INTERAKTIF BERBASIS TUTORIAL PADA MATA PELAJARAN KELISTRIKAN OTOMOTIF DI KELAS XI JURUSAN TEKNIK KENDARAAN RINGAN SMK N 1 LAHAT
}

\author{
Aris Puja Widikda ${ }^{*}$, Kasman Rukun ${ }^{2}$ dan Wakhinuddin ${ }^{3}$ \\ ${ }^{1}$ Akademi Komunitas Negeri Lahat \\ ${ }^{23}$ Universitas Negeri Padang \\ "Corresponding author, e-mail: widikda@yahoo.co.id
}

\begin{abstract}
Abstrak - Penelitian ini bertujuan untuk mengembangkan media pembelajaran interaktif pada mata pelajaran Kelistrikan Otomotif di jurusan Teknik Kendaraan Ringan SMK N 1 Lahat. Penelitian ini menggunakan metode Research and Development $(R \& D)$ dan penelitian ini juga menggunakan model pengembangan 4D (four-D), yang terdiri dari empat tahapan, yaitu define (pendefinisian), design (perencanaan), develop (pengembangan), dessiminate (penyebaran). Teknik analisa data yang digunakan adalah teknik analisis data deskriptif untuk menentukan kevalidan, kepraktisan dan keefektifan media pembelajaran interaktif pada mata pelajaran Kelistrikan Otomotif. Media pembelajaran ini dirancang dengan menggunakan Lectora Inspire. Hasil yang diperoleh dari penelitian ini adalah sebagai berikut: (1) Validitas media pembelajaran interaktif dinyatakan valid pada validasi ahli materi dengan nilai 0,95 dan pada validasi ahli media dinyatakan valid dengan nilai 0,93 , (2) Praktikalitas media pembelajaran interaktif berdasarkan respon guru dinyatakan sangat praktis dengan nilai 96,11 dan berdasarkan respon siswa dinyatakan sangat praktis dengan nilai 90,54, (3) Efektivitas media pembelajaran interaktif dinyatakan efektif dalam meningkatkan hasil belajar siswa dimana rata-rata pretest $61,46 \%$ menjadi rata-rata postest $81,37 \%$. Berdasarkan temuan penelitian ini disimpulkan bahwa media pembelajaran interaktif pada mata pelajaran Kelistrikan Otomotif ini valid, praktis, dan efektif untuk dimanfaatkan sebagai sebuah media pembelajaran.
\end{abstract}

Kata Kunci : Media Pembelajaran Interaktif, Lectora Inspire, Hasil Belajar

Abstract-This study aims to develop interactive learning media on the subjects of Automotive Electricity in the Department of Light Vehicle Engineering SMK N 1 Lahat. This research uses the Research and Development (R \& D) method and this research also uses $4 D$ (four-D) development model, which consists of four stages, define, design, develop, and disseminate. Data analysis techniques used are descriptive data analysis techniques to determine validity, practicality and effectiveness of interactive learning media in Automotive Electrical subjects. This learning medium is designed using Lectora Inspire. The results obtained from this research are as follows: (1) Validity of interactive learning media is valid on validation of material expert with value 0,95 and validation of media expert expressed valid with value 0,93, (2) Practicality of interactive learning media based on response the teacher is considered very practical with a value of 96.11 and based on the response of students stated very practical with a value of 90.54, (3) Effectiveness of interactive learning media declared effective in improving student learning outcomes when mean of pretest 61,46 become mean of posttest $81.37 \%$. Based on the findings of this study concluded that interactive learning media on Automotive Electrical subjects is valid, practical, and effective to be used as a media of learning.

Keywords: Interactive Learning Media, Lectora Inspire, Learning Outcomes

\section{Pendahuluan}

Pemilihan media yang tepat akan mengakibatkan perubahan orientasi belajar mengajar dari guru sebagai sumber informasi ke arah orientasi belajar siswa aktif mencari informasi dari berbagai media [1][2]. Tentunya dibutuhkan disiplin yang tinggi, kemauan yang kuat serta motivasi untuk dapat meraih prestasi yang tinggi. Menurut Djamarah dalam proses belajar mengajar kehadiran media mempunyai arti yang cukup penting. Ketidakjelasan bahan yang disampaikan tersebut dapat dibantu dengan kehadiran media sebagai 
perantara[3]. Kerumitan bahan yang akan disampaikan kepada siswa dapat disederhanakan dengan bantuan media [4]. Media dapat mewakili apa yang kurang mampu guru ucapkan melalui katakata atau kalimat tertentu. Bahkan keabstrakan bahan dapat dikonkretkan dengan kehadiran media. Dengan demikian, anak didik lebih mudah mencerna bahan dari pada tanpa bantuan media.

Teknologi terutama media pembelajaran mempunyai peran penting dalam proses pembelajaran. Banyak orang percaya bahwa media pembelajaran dapat membawa pada situasi pembelajaran yang menyenangkan, kreatif, dan tidak membosankan [5][6]. Dalam proses pembelajaran selain guru dan siswa, dua unsur yang sangat penting adalah metode pembelajaran dan media pembelajaran. Kedua aspek ini saling berkaitan [7]. Pendekatan dan metode yang dirumuskan harus mampu mengoptimalkan motivasi belajar mandiri, mengefektifkan proses belajar siswa dan mampu mengimbangi pesatnya pengetahuan dan teknologi yang berkembang.

Komputer merupakan alat bantu mengajar yang dapat memberikan ilustrasi, grafik dan animasi yang menarik. Komputer diharapkan mampu menjadi media altrnatif untuk mengefektifkan pembelajaran karena aplikasi dalam komputer mampu menghadirkan suasana belajar yang nyaman dan kemungkinan mendapat respons positif siswa cukup besar [8].

Pada kenyataanya pemanfaatan media pembelajaran berbasis komputer di sekolah tidak seiring dengan perkembangan dan kemajuan teknologi informasi yang dapat digunakan untuk mendukung penyampaian media pembelajaran. Penyampaian materi yang memerlukan media, apabila disampaikan tanpa media akan menjadikan siswa cepat bosan dalam proses pembelajaran.

Berdasarkan hasil observasi di lapangan pada tanggal 1 Mei sampai tanggal 2 Juni 2017 fenomena yang ditemukan dalam proses pembelajaran di SMK Negeri 1 Lahat antara lain; keterbatasan dalam pengadaan media pembelajaran sehingga guru belum menemukan cara yang tepat dalam penyajian materi yang tidak bisa disajikan dengan metode ceramah dan mencatat. Fenomena tersebut membawa dampak negatif bagi siswa, sehingga siswa harus mengulangulang materi, juga menghabiskan waktu yang seharusnya bisa digunakan untuk pembahasan materi selanjutnya yang dapat menambah pengetahuan siswa, dan mengakibatkan siswa tidak aktif dalam pembelajaran dikarenakan lebih banyak kegiatan untuk mendengar saja.

Persentase kelulusan siswa pada mata pelajaran kelistrikan otomotif 55,522\% atau lebih dari separo siswa yang tidak melewati batas Kriteria
Ketuntasan Minimum (KKM). Hasil pengamatan penulis banyak faktor yang menyebabkan hasil belajar siswa tersebut tidak mencapai KKM, diantaranya yaitu masih kurangnya pemahaman siswa tentang materi yang disampaikan, belum adanya pemanfaatan media pembelajaran yang efektif, keterbatasan waktu dalam proses pembelajaran sehingga pembelajaran terutama kelistrikan otomotif hanya disampaikan dengan modul konvensional.

Keterbatasan waktu dalam penyampaian materi secara lebih mendalam sehingga materi tidak seluruhnya bisa disampaikan ke siswa dan minimalnya sarana pendukung pembelajaran seperti tidak optimalnya pemanfaatan media pembelajaran seperti buku pelajaran dan sarana laboratorium komputer yang menyebabkan kurang optimal pemahaman siswa terhadap materi pembelajaran. Penggunaan buku pelajaran yang terbatas dikarenakan ketersediaan buku pelajaran yang tidak mencukupi dan terbitan lama, sehingga siswa tidak mempunyai buku terbaru, terutama di bidang media pembelajaran.

Penggunaan media yang belum maksimal dalam pembelajaran. Penggunaan media pembelajaran yang belum mendukung bahan ajar, media power point digunakan oleh guru dalam proses pembelajaran sebagai media tambahan dalam pembelajaran di dalam kelas dan pembelajaran mandiri siswa. Akan tetapi, media yang digunakan tersebut memiliki kekurangan yaitu hanya berisikan materi pembelajaran tanpa adanya animasi pendukung dan latihan/kuis didalamnya sehingga kurangnya interaksi siswa dalam pembelajaran.

Media pembelajaran yang bersifat interaktif sangat diperlukan saat proses pembelajaran Kelistrikan Otomotif karena tidak semua materi pelajaran ini dapat dipahami dengan hanya membaca namun memerlukan media dalam menampilkan sesuatu yang bersifat abstrak yang sulit dipahami siswa. Oleh karena itu, dengan adanya media pembelajaran interaktif diharapkan dapat menampilkan sesuatu yang bersifat abstrak dan sulit dipahami sehingga mempermudah pemahaman konsep.

Sejalan dengan hal tersebut beberapa penelitian yang dilakukan oleh Deno Puyada membahas tentang media pembelajaran interaktif yang valid, praktis dan efektif dapat meningkatkan hasil belajar siswa. Penggunaan software lectora mampu membuat media pembelajaran interaktif sehingga materi yang disampaikan dapat direspon positif oleh siswa [9].

Hal lain juga dilihat dari proses pembelajaran di SMK N 1 Lahat masih dilakukan secara konvensional, dimana proses pembelajaran masih 
terpusat pada guru, hal inilah yang menyebabkan siswa kurang termotivasi untuk menemukan sendiri hal-hal baru yang dapat dijadikan sebagai pengalaman dalam proses pembelajaran. Hal tersebut mengakibatkan pembelajaran kurang menarik dan kurang optimal. Dengan demikian proses pembelajaran menjadi terhambat dan berpengaruh pada nilai hasil belajar siswa.

Proses pembelajaran yang terpusat pada guru (teacher centered) diubah menjadi terpusat kepada siswa (student centered) membutuhkan model pembelajaran yang baik dan benar. Salah satu model pembelajarannya adalah model tutorial. Menurut Darmawan model tutorial bertujuan untuk memberikan kepuasan atau pemahaman secara tuntas kepada siswa mengenai materi atau bahan pelajaran yang sedang dipelajarinya [10].

Media pembelajaran interaktif berbasis tutorial diharapkan mampu meningkatkan hasil belajar siswa. Media pembelajaran interaktif berbasis tutorial ini nantinya akan memberikan kepuasan atau pemahaman secara tuntas kepada siswa mengenai materi atau bahan pelajaran yang sedang dipelajarinya karena diberikan dengan animasi pendukung dan latihan/kuis sehingga menjadikan pembelajaran yang menarik dan menyenangkan.

\section{METODE}

Penelitian ini adalah penelitian pengembangan (Research and Development), hal ini dapat dilihat berdasarkan rumusan masalah yang diungkap sebelumnya. Dalam penelitian pengembangan ini produk yang dihasilkan berupa media pembelajaran menggunakan software Lectora Inspire. Menurut Sugiyono Metode penelitian pengembangan dapat diartikan sebagai cara ilmiah untuk meneliti, merancang, memproduksi dan menguji validitas produk yang telah dihasilkan [11].

Penelitian dan pengembangan sering disebut "jembatan" antara penelitian dasar (basic research) dengan penelitian terapan (applied research). Menghasilkan produk tertentu digunakan penelitian yang bersifat analisis kebutuhan dan untuk menguji keefektifan produk tersebut supaya dapat berfungsi di masyarakat luas, maka diperlukan penelitian untuk menguji keefektifan produk tersebut [11]. Model yang dipilih dalam penelitian ini adalah model 4-D (four-D) karena model pengembangan tersebut mempunyai prosedur yang sistematis, sesuai dengan masalah yang melatar belakangi penelitian ini. Prosedur pengembangan media pembelajaran interaktif dengan menggunakan model tutorial ini menggunakan menggunakan model pengembangan 4-D (four- $D)$. Proses pengembangan yang terdiri dari 4 tahap yaitu: (1) define (penentuan materi); (2) design (perancangan); (3) develop (pengembangan); (4) disseminate (penyebaran) [12].

Pelaksanaan uji coba produk media dilakukan setelah rancangan produk draf awal divalidasi oleh ahli. Uji coba produk merupakan tahap penilaian dengan tujuan untuk mengetahui apakah produk yang dihasilkan telah valid, praktis dan efektif untuk digunakan dalam kegiatan pembelajaran atau tidak dengan mempertimbangkan kesesuaian antara produk media dengan pengguna dalam menyelesaikan masalah pada mata pelajaran Kelistrikan Otomotif serta untuk mengetahui sejauh mana media yang dihasilkan dapat mencapai tujuan pembelajaran yang diinginkan. Hasil uji coba juga untuk mengetahui dalam hal media yang menarik. Subjek uji coba dilakukan pada siswa kelas XI Teknik Kendaraan Ringan SMK N 1 Lahat. Uji coba produk ini dimaksudkan untuk mengumpulkan data tentang kualitas media pembelajaran untuk mencapai standar kompetensi yang efektif dan untuk melihat respon siswa terhadap media yang telah dikembangkan. Data- data tersebut digunakan untuk memperbaiki dan menyempurnakan media pembelajaran interaktif dengan menggunakan model tutorial yang merupakan produk dalam penelitian ini.

Instrumen yang digunakan berupa angket untuk mengukur uji validitas dan praktikalitas sedangkan untuk uji efektifitas digunakan soal tes.

\section{HASIL DAN PEMBAHASAN}

\section{Tahap Pendefinisian (Define)}

Penelitian ini dimulai dengan pengumpulan data sebelum pembuatan media pembelajaran yaitu tahap pendefinisian. Tahap Define ini bertujuan untuk memunculkan dan menetapkan masalah dasar yang dihadapi dalam pembelajaran, dengan analisis ini akan didapat gambaran fakta, hamparan dan alternatif penyelesaian masalah dasar. Tahap pendefinisian merupakan tahap awal pengembangan media. Tahap ini dilakukan sebagai dasar untuk mengembangkan media pembelajaran interaktif pada mata pelajaran Menganalisis Kelistrikan Otomotif sehingga dapat digunakan untuk memfasilitasi siswa secara mandiri.

Tahap ini merupakan analisis kebutuhan dimana pada tahap ini dilakukan tiga kegiatan, yaitu observasi, analisis kurikulum, analisis siswa dan analisis kebutuhan. Dimana hasil dari keempat analisis tersebut akan dijadikan pedoman bagi peneliti dalam mengembangkan media pembelajaran interaktif pada mata pelajaran Kelistrikan Otomotif ini. 


\section{Tahap Perancangan (Design Phase)}

Setelah melakukan analisis kebutuhan, dilanjutkan melakukan mengembangkan produk awal atau prototype dari media pembelajaran interaktif ini kemudian pembuatan media pembelajaran interaktif ini berdasarkan produk awal atau prototype yang telah dibuat. Penelitian ini menghasilkan suatu produk berupa Media Pembelajaran Interaktif (MPI) dengan menggunakan Lectora Inspire yang diintegrasikan dengan Macromedia Flash pada standar kompetensi Menganalisis Kelistrikan Otomotif di SMK kelas XI yang layak untuk digunakan sebagai media pembelajaran.

1) Halaman pembuka yang merupakan tampilan awal ketika media ini pertama kali dibuka. Pada halaman awal terdapat musik dan animasi teks nama media pembelajaran interaktif tersebut. Pada halaman awal ini juga terdapat satu tombol yang akan membawa pengguna ke halaman menu. Tampilan halaman awal dari media pembelajaran interaktif Kelistrikan Otomotif ini dapat dilihat pada gambar berikut.

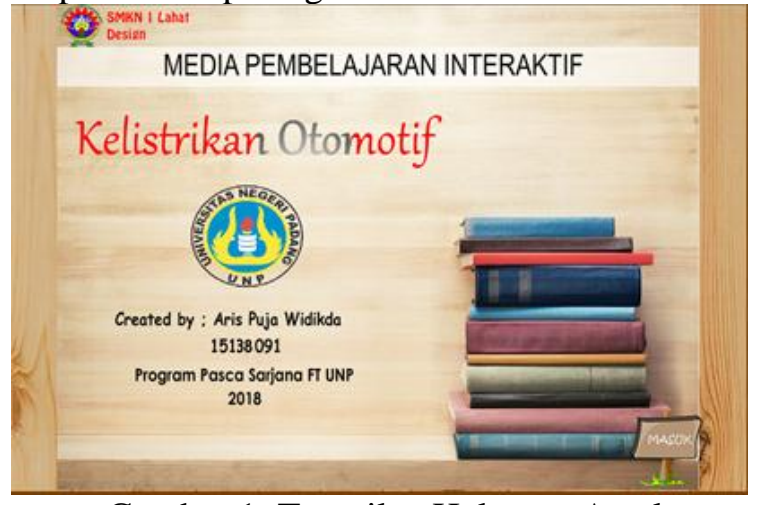

Gambar 1. Tampilan Halaman Awal

2) Tampilan Halaman Menu merupakan halaman awal media pembelajaran interaktif yang terdiri dari layout menu, tombol home dan beberapa tombol menu, antara lain: SK dan KD, Komponen Media Pembelajaran, materi, video, latihan, evaluasi, profile, petunjuk, dan intro. Fungsi masing-masing tombol navigasi pada halaman menu utama adalah untuk mengantarkan pengguna ke halaman masing-masing menu tersebut. Tampilan halaman menu utama dapat dilihat pada gambar di bawah ini.

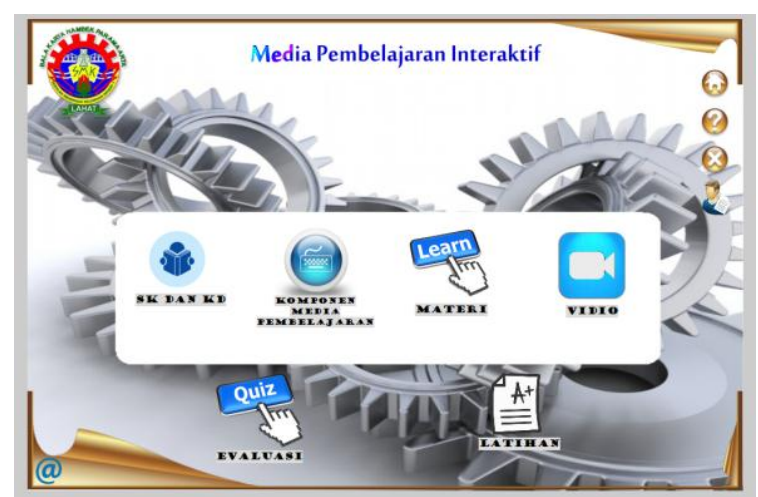

Gambar 2. Tampilan Halaman Menu

3) Halaman menu SK/KD merupakan halaman awal media yang terdiri dari layout dan teks $\mathrm{KI} / \mathrm{KD}$, tombol home dan beberapa tombol menu, antara lain: materi, evaluasi, profile, petunjuk, dan intro. Fungsi masing-masing tombol navigasi pada halaman menu utama adalah untuk mengantarkan pengguna ke halaman masingmasing menu tersebut. Tampilan halaman menu utama dapat dilihat pada gambar di bawah ini.



Gambar 3. Tampilan Halaman SK/KD

4) Halaman menu materi, merupakan halaman yang berisikan materi- materi yang akan dipelajari yang terdiri dari materi 1, materi 2, yang dimana dalam setiap materi tersebut terdiri dari beberapa sub-sub materi. Adapun tampilan halaman menu materi seperti pada gambar di bawah ini.

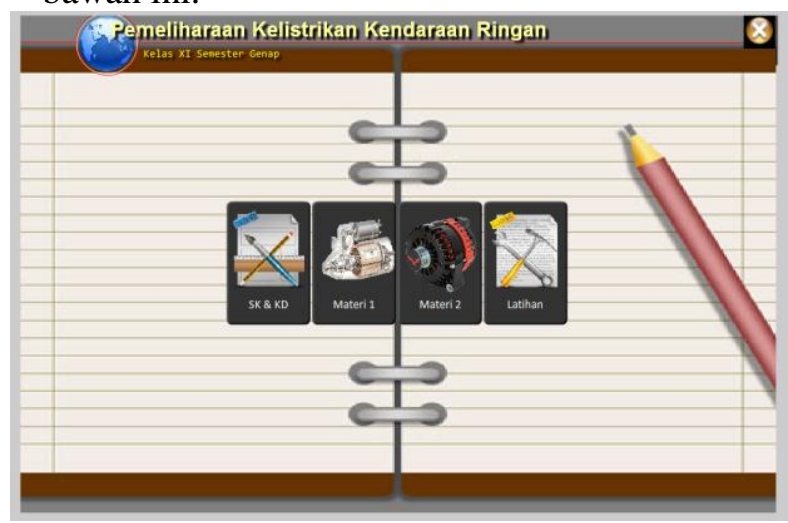

Gambar 4. Tampilan Halaman Materi 
5) Halaman Evaluasi, berisi soal-soal yang hendak menguji kemampuan siswa terhadap materi yang disajikan dalam media pembelajaran. Pada halaman evaluasi ini terdapat dua macam evaluasi, dimana siswa dengan nomor induk ganjil akan dapat soal yang berbeda dengan siswa dengan nomor induk genap. Tampilan halaman evaluasi dapat dilihat pada gambar di bawah ini.

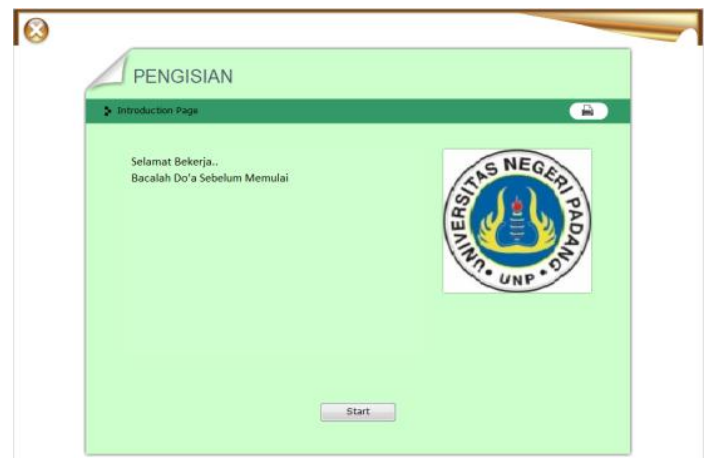

Gambar 5. Tampilan Awal Halaman Evaluasi



Gambar 6. Tampilan Halaman Soal

Evaluasi ini dirancang menjadi lebih interaktif dengan memberikan feedback kepada siswa ketika menjawab soal. Jika jawaban yang dipilih siswa benar, maka akan mucul "Benar" pada layar dan jika jawaban yang dipilih siswa salah, pada layar akan muncul "Salah" dan tampilan feedback yang salah akan disertakan dengan jawaban benar dari setiap soal tersebut. Hal ini membuat pembelajaran menjadi lebih interaktif dan menyenangkan. Tampilan halaman "Benar" dan "Salah" dapat dilihat pada gambar di bawah ini.

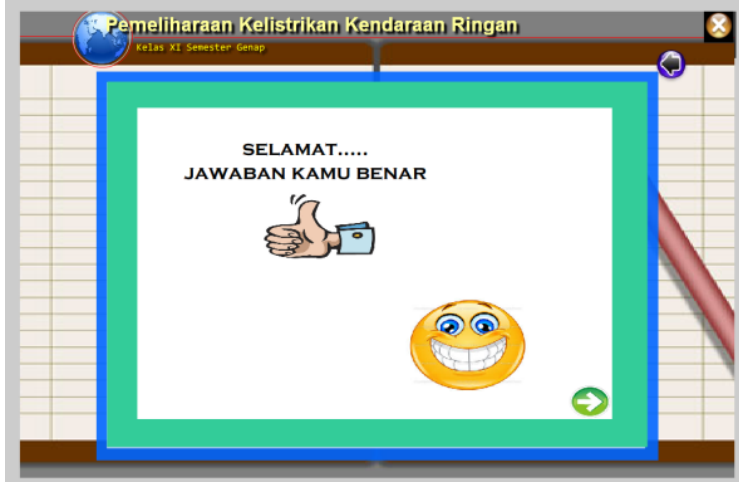

Gambar 7. Tampilan Halaman Benar

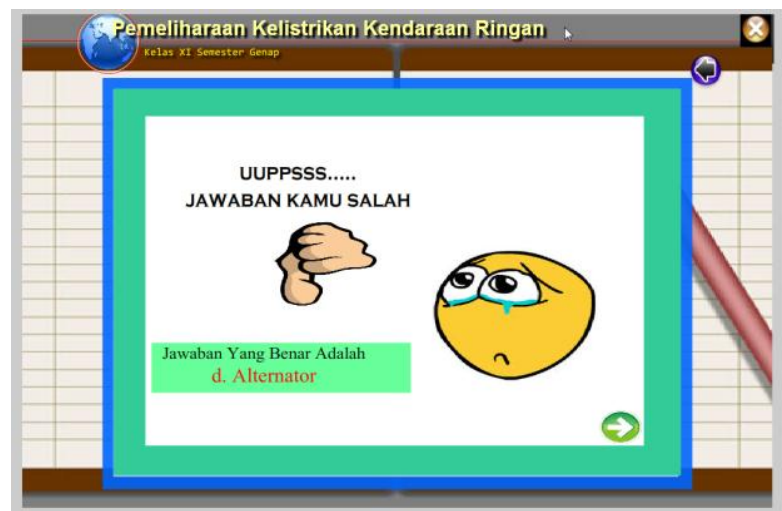

Gambar 8. Tampilan Halaman Salah

Setelah siswa menyelesaikan semua soal pada media interaktif, akan mucul skor yang diperoleh oleh siswa selama mengerjakan evaluasi tersebut. Adapun tampilan halaman hasil evaluasi dapat dilihat pada gambar berikut ini:

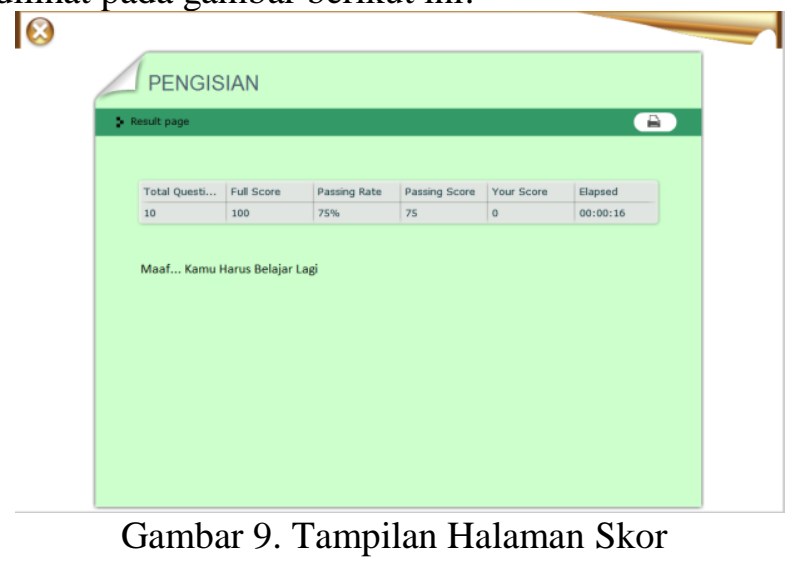

6) Halaman menu profil, berisikan tentang profil penulis dan memuat animasi teks dan terdapat satu tombol navigasi yaitu tombol home yang akan mengantarkan pengguna kembali ke halaman menu utama. Adapun tampilan halaman profil dapat dilihat padaa gambar di bawah ini. 




Gambar 10. Tampilan Halaman Profil

7) Halaman petunjuk terdiri dari animasi teks dan layout petunjuk penggunaan media, serta penjelasan penggunaan tombol yang terdapat dalam media pembelajaran. Pada halaman petunjuk ini terdapat satu tombol navigasi, yaitu tombol home yang akan mengantarkan pengguna kembali ke halaman menu utama. Tampilan Halaman petunjuk dapat dilihat pada gambar di bawah ini.

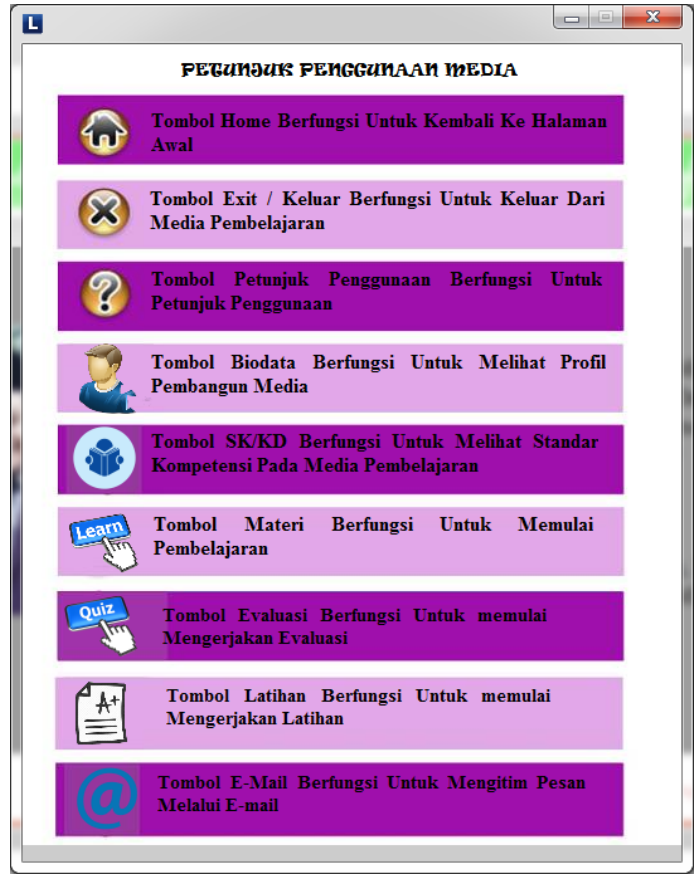

Gambar 11. Tampilan Halaman Petunjuk

8) Halaman interaktif. Memberikan petunjuk penjelasan teks / gambar di beberapa kata/ istilah yang asing

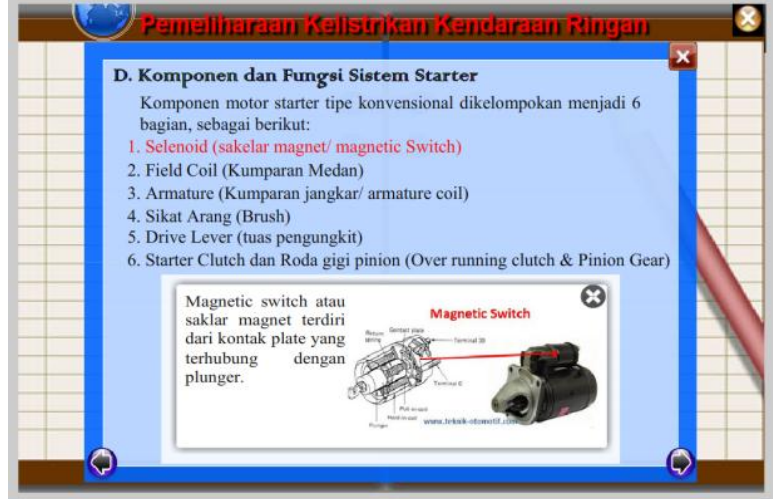

Gambar.12. Tampilan Halaman Interaktif

9) Halaman video menayangkan video praktek berkaitan dengan ki kd

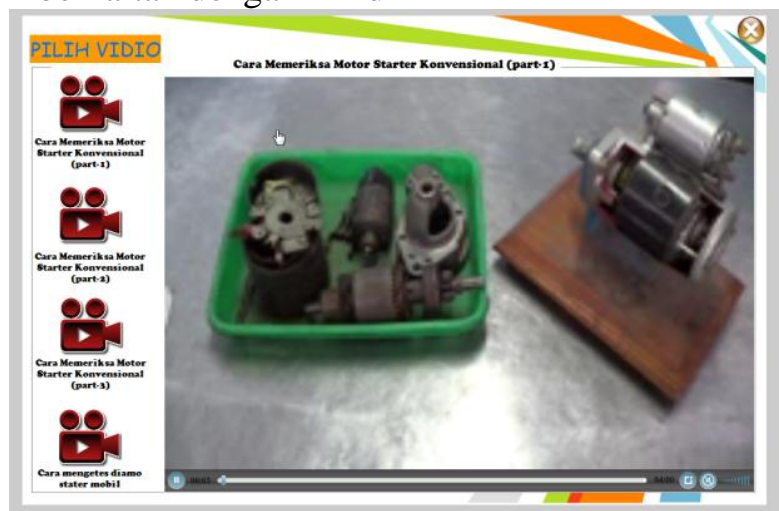

Gambar 13. Tampilan Halaman Video

10) Ada tambahan halaman kuis interaktif jika belum bisa menjawab bisa mengulangi materi lagi dengan menekan tombol ulangi, atau lewati. Tetapi jika jawaban benar maka ada menu untuk menuju materi selanjutnya

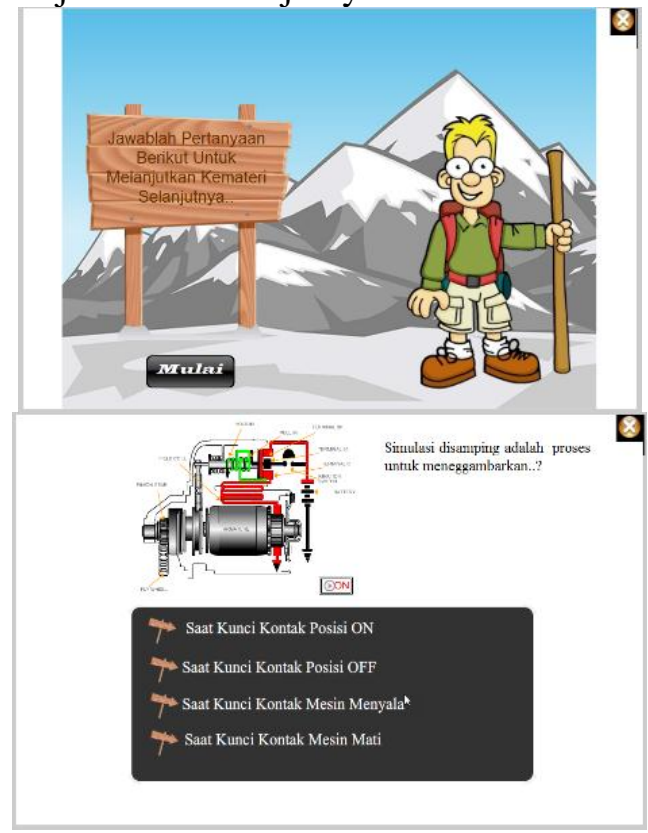






Gambar 14. Tampilan Halaman Kuis Interaktif

\section{Tahap Pengembangan (Develop)}

Tahap pengembangan bertujuan untuk menghasilkan media pembelajaran interaktif yang valid, praktis, dan efektif. Tahap pengembangan yang dimaksud meliputi:

\section{a. Tahap Validasi Media Pembelajaran Interaktif}

Tujuan dari validasi oleh ahli adalah untuk memperoleh masukan, kritik, dan saran perbaikan untuk kesempurnaan media yang dikembangkan. Data uji validasi diperoleh melalui instrumen validasi yang diisi oleh beberapa orang validator yang merupakan ahli media pembelajaran. Validator terdiri dari 4 orang yaitu dua orang untuk validator media dan dua orang untuk validator materi. Validasi ahli media difokuskan pada tampilan atau penyajian yang dilihat dari sudut pandang media. Validasi oleh ahli media bertujuan agar produk media pembelajaran interaktif berbasis tutorial yang dikembangkan menjadi produk yang berkualitas secara aspek pemograman dan tampilan.

Data dari validator diperoleh dari angket yang telah diberikan penilaian oleh 4 orang validator. Validator memberikan nilai rata-rata sebesar 0,95, sehingga dapat dikatakan bahwa desain media pembelajaran interaktif ini valid. Berdasarkan saran dan penilaian dari validator baik dari segi isi dan desain maka dilakukan revisi terhadap media pembelajaran interaktif ini, sehingga media pembelajaran interaktif yang dikembangkan layak untuk diujicobakan.

Dari hasil validasi materi oleh ahli dapat diketahui bahwa media pembelajaran interaktif yang telah dikembangkan mencapai kategori valid dengan skor rata-rata kevalidan sebesar 0,93 . Hasil penilaian ini juga sejalan dengan hasil-hasil penelitian yang terdahulu yang dilakukan oleh I Gede Martha yang menunjukkan persentase hasil pencapaian skor ratarata sebesar 95,35\% dalam kategori sangat valid, sehingga dilihat dari segi kebenaran ketepatan materi dalam media, media pembelajaran interaktif tersebut layak untuk diujicobakan di lapangan [13].

\section{b. Kepraktisan Media Pembelajaran Interaktif}

Data kepraktisan media pembelajaran interaktif diambil melalui uji yang dilakukan di S M K Negeri 1 Lahat yang bertujuan untuk melihat keterlaksanaan pembelajaran dengan menggunakan media pembelajaran interaktif ini. Untuk melihat kepraktisan, media pembelajaran interaktif yang telah valid digunakan dalam proses pembelajaran oleh guru. Di akhir pembelajaran, guru dan siswa diminta mengisi angket kepraktisan dari media pembelajaran interaktif yang telah digunakan.

Penilaian terhadap kepraktisan media pembelajaran interaktif ini diperoleh dari angket yang diisi oleh guru praktisi dan hasil penilaian yang diperoleh dari angket respon guru terhadap praktikalitas media pembelajaran interaktif ini adalah sebesar 96,11\% dengan kategori kepraktisan sangat praktis. Selain penilaian dari guru/praktisi, kepraktisan medi pembelajaran interaktif ini juga dinilai berdasarkan tanggapan siswa dan hasil diketahui padaangket respon siswa yaitu diperoleh nilai sebesar 90,54\% sehingga dapat disimpulkan bahwa media pembelajaran interaktif yang dikembangkan adalah praktis dengan kategori kepraktisan sangat praktis. Menurut Yulastri produk dikatakan praktis apabila orang yang menggunakan produk tersebut menganggap bahwa produk tersebut dapat digunakan [14].

\section{c. Efektivitas Media Pembelajaran Interaktif}

Keefektifan media pembelajaran interaktif pada penelitian ini dilihat digunakan untuk memudahkan siswa dalam memahami materi pembelajaran, serta keefektifan dari media pembelajaran interaktif yang digunakan dapat dilihat dari hasil belajar kognitif siswa. Hasil belajar adalah kemampuan yang dimiliki siswa setelah mereka 
melalui proses pengalaman belajar. Hasil belajar didapatkan dari pretest dan postest 53 orang siswa yang diberikan dalam bentuk tes objektif sebanyak 40 butir soal. Berdasarkan data yang diperoleh dari hasil uji media pembelajaran interaktif ini maka peneliti dapat menjelaskan bahwa terdapat perbedaan yang signifikan pada hasil kelas pre test dan post test.

Hasil penelitian ini relevan dengan penelitian yang dilakukan Irma yang memperoleh hasil uji efektivitas hasil belajar siswa sebesar $84,48 \%$ untuk standar kompetensi 1, 93,64\% untuk standar kompetensi 2, 77,93 untuk standar kompetensi 3, dan 93,56\% untuk standar kompetensi 4, dalam kategori sangat baik dan penelitian I Gede Martha dengan persentase keefektivan sebesar 86,82\% dalam kategori sangat efektif dan dapat meningkatkan hasil belajar siswa. Sehingga dilihat dari hasil belajar kognitif siswa yang mengikuti pelajaran dengan menggunakan media pembelajaran interaktif, menunjukkan bahwa media pembelajaran interaktif yang dikembangkan peneliti efektif untuk meningkatkan hasil belajar siswa [15].

\section{Tahap Penyebaran (Disseminate)}

Tahap penyebarluasan atau diseminasi dilakukan dengan cara penerapan Media pembelajaran interaktif ini didalam proses belajar mengajar pada mata pelajaran Kelistrikan Otomotif yang disebarkan pada kelas lain yaitu kelas XI TKR SMK N 1 Lahat. Penyebaran dapat juga dilakukan melalui sebuah proses penularan kepada praktisi pembelajaran terkait dalam suatu forum tertentu

\section{KESIMPULAN}

Berdasarkan hasil penelitian pengembangan media pembelajaran interaktif yang telah dilakukan, maka diperoleh kesimpulan sebagai berikut:

1. Penelitian pengembangan media pembelajaran interaktif berbasis tutorial pada mata pelajaran Kelistrikan Otomotif Kelas XI semester genap. Proses pengembangan media pembelajaran interaktif ini mengacu pada model pengembangan 4-D yaitu Define (Pendefinisian), Design (Perancangan), Develop (Pengembangan), dan Dessiminate (Penyebaran).

2. Validitas media pembelajaran interaktif berbasis tutorial sudah memenuhi tampilan atau penyajian yang dilihat dari sudut pandang media. Jadi dapat disimpulkan media pembelajaran interaktif berbasis tutorial yang dikembangkan sudah valid untuk digunakan pada pembelajaran.

3. Praktikalitas media pembelajaran interaktif berbasis tutorial dapat dilihat dari keterlaksanaan penggunaan media pembelajaran interaktif berbasis tutorial secara keseluruhan dengan baik.
Ini terlihat dari hasil respon dosen dan siswa yang menunjukkan media pembelajaran interaktif berbasis tutorial yang dikembangkan termasuk pada kategori sangat praktis.

4. Efektivitas media pembelajaran interaktif berbasis tutorial yang dikembangkan terhadap siswa dilihat dari hasil belajar siswa yang mengikuti tes sebelum menggunakan media pembelajaran interaktif berbasis tutorial dengan setelah menggunakan media pembelajaran interaktif berbasis tutorial menunjukan bahwa adanya peningkatan hasil belajar. Jadi, dapat disimpulkan bahwa pembelajaran dengan menggunakan media pembelajaran interaktif berbasis tutorial dapat dikatakan efektif dalam meningkatkan hasil belajar siswa.

\section{DAfTAR Pustaka}

[1] D. Pernanda, M. A. Zaus, R. E. Wulansari, and S. Islami, "Effectiveness of instructional media based on interactive cd learning on basic network at vocational high school: improving student cognitive ability," Int. Conf. Educ. Soc. Sci. Technol., no. January, pp. 440-444, 2018.

[2] M. A. Zaus, R. E. Wulansari, S. Islami, and D. Pernanda, "Perancangan Media Pembelajaran Listrik Statis dan Dinamis Berbasis Android," vol. 1, no. 1, pp. 1-7, 2018.

[3] Z. A. Putra, Arwizet, B. Rahim, and R. A. Nabawi, "The Practicality of Learning Module Based on Education Course," vol. 201, no. Aptekindo, pp. 48-52, 2018.

[4] R. Lapisa, I. Y. Basri, A. Arif, and H. D. Saputra, "PENINGKATAN KOMPETENSI SISWA MELALUI PELATIHAN AUTO CAD," vol. 17, no. 2, 2017.

[5] M. A. Zaus, "Suatu Kajian Literatur MasalahMasalah yang Dihadapi dalam Mata Kuliah Jaringan Komputer," vol. 18, no. 1, pp. 1-8, 2018.

[6] N. Jalinus, Syahril, and R. A. Nabawi, "Effectivity of The Cooperative-Project Based Learning ( CPjBL ) in Enhancing HOTS of Vocational Education Students," no. 1, pp. 83-86, 2018.

[7] R. E. Wulansari, D. Puyada, I. Wijaya, and K. Rukun, "EFFECTIVENESS OF INSTRUCTIONAL MEDIA BASED GAME ON MATHEMATICS AT VOCATIONAL HIGH SCHOOL," Int. J. Res. Sci. Manag., vol. 4, no. 12, pp. 125-128, 2017.

[8] S. Sukardi, D. Puyada, R. E. Wulansari, and D. T. P. Yanto, "The validity of interactive instructional media on electrical circuits at vocational high school and technology," in the 2nd INCOTEPD, 2017, vol. 2017, no. October, pp. 21-22.

[9] Djamarah, Syaiful Bahri. 2002. Strategi Belajar Mengajar. Jakarta : Rineka Cipta.

[10] Deno Puyada. 2016. Pengembangan Media Pembelajaran Interaktif Pada Mata Pelajaran Rangkaian Listrik di Kelas X Jurusan Teknik Ketenagalistrikan SMKN 2 Lubuk Basung. Tesis 
Pascasarjana Fakultas Teknik Universitas Negeri Padang.

[11] Darmawan, Deni. 2012. Inovasi Pendidikan. Bandung: PT. Remaja Rosdakarya Offset.

[12] Sugiyono. 2012. Metode Penelitian Pendekatan Kualitatif, Kuantitatif dan R\&D. Bandung : Alfabeta.

[13] Trianto. 2009. Mendesain Model Pembelajaran Inovatif Progresif. Jakarta: Kencana.

[14] I Gede Martha Adi Pariartha. 2012. Pengembangan Media Pembelajaran Berbasis Multimedia Interaktif Pada Mata Pelajaran IPA Untuk Siswa Kelas VIII Semester 1 Di SMP Negeri 3 Singaraja Tahun Pelajaran 2012/2013. Tesis. Program Magister Fakultas Teknik Universitas Negeri Padang

[15] Yulastri, A., Hidayat, H., Ganefri, Islami, S. \& Edya, F. (2017). Developing an Entrepreneurship Module by Using Product-Based Learning Approach in Vocational Education. International Journal of Environmental and Science Education, 12(5), 1097-1109.

\section{Biodata Penulis}

Aris Puja Widikda, lahir di Madiun, 16 April 1990. Sarjana Pendidikan di Jurusan Teknik Mesin Konsentrasi Keahlian Teknik Otomotif FKIP UNS 2013. Tahun 2018 memperoleh gelar Magister Pendidikan di jurusan Pendidikan Teknologi dan Kejuruan Program Pascasarjana UNP dengan bidang konsentrasi Teknik Otomotif. Staf pengajar di jurusan Teknik Otomotif PDD FT UNP Kab. Lahat, Serta di SMKN 1 Lahat Sumatera Selatan. sejak tahun 2015- sekarang. 